\title{
Determinants of Social Poverty in Mountainous Areas of Talegong, Garut Regency
}

\author{
${ }^{1}$ TASYA ASPIRANTI, 2 IMA AMALIAH \\ 1,2 Management Program, Economics Study, Universitas Islam Bandung, Jl. Tamansari No. 1 Bandung \\ email: 1ad_tasya@yahoo.com, 2amalia.razi@gmail.com
}

\begin{abstract}
Poverty is a multidimensional problem since it is not only an economic problem but also a social, political and even cultural problem. The purpose of this research is to identify the determinant factor of social poverty in the mountain region of Talegong Subdistrict. This research uses a quantitative descriptive analysis with field survey method. The analysis technique using descriptive statistics and the sample is determined by purposive random sampling. The concept of social poverty uses BPS and Chambers indicators. Respondents interviewed were village heads, LPMDes, community leaders and communities in seven villages in Talegong sub-district. Based on the results of observations and interviews with respondents, there are four determinants of social poverty in Talegong sub-district: the factor of poverty itself, abandonment, alienation \& remoteness and vulnerable to natural disasters. While three other factors such as physical, mental and social neglect factors; social impairment factor and behavioral deviation from religious and community norms, and factors of victims and physical, mental and social violence were not found in Talegong sub-district.
\end{abstract}

Keyword: Poverty, Disability, Alienation \& Remoteness, Natural Disasters

\section{Introduction}

Poverty is a phenomenon that has recently been intensively discussed by various stakeholders, especially the government, both central and local government. According to the Central Bureau of Statistics (BPS), a person is considered poor if he or she is not able to meet the minimum living needs. The minimum requirement of life is the need to consume food in a dose of 2,100 kilocalories per person per day and minimum non food requirements such as housing, education, health and transportation. Furthermore, BPS uses the poverty line of 220,000 Rupiahs per capita per month (Hermawan, 2012; 139). In West Java, number of people living below the poverty line is still high. Based on BPS data, the number of poor people in West Java in March 2016 was 4,224,325 (8,95 percent of the total population) which was lower than the number of poor people in September 2015 of $4,485,654$ people $(9,57$ percent). Out of 4,224,325 poor people, 7.67 $\%$ were in urban areas and $11.80 \%$ were in rural areas (BPS, 2017). This means that the number of poor people in the rural areas of west Java was much more than it is of urban areas. The reason for this is that in rural areas there are fewer economic activities that can be utilized by society because people find it difficult to get a job.The effect was that the number of people in poverty in the rural areas is still high. Meanwhile, in West Java, the number of poor people in regency of Garut was identified to be in third place after Cirebon regency with 365,390 poor people in 2016 (BPS, 2017). Furthermore, Tasya Aspiranti, Ima Amaliah, Pupung Purnamasari and Sri Suwarsi (2016) found out that in 2015, Garut regency was the poorest area after Bogor Regency and Cirebon Regency. Regarding household expenditure on food and non-food items as well as the amount of protein consumed by people, Garut Regency has the lowest spending level compared to other districts in West Java. Meanwhile, based on floor area per capita, Garut regency is the smallest area. In addition, regarding the communication infrastructure ownership aspect, people of Garut regency do not have adequate access to information technology (wired-phone or computer) (BPS, 2017). The availability of minimal facilities and

Received: August 22, 2017, Revision: January 15, 2018, Accepted: June 04, 2018

Print ISSN: 0215-8175; Online ISSN: 2303-2499. DOI: http://dx.doi.org/10.29313/mimbar.v34i1.2872.33-42

Accredited B based on the decree No.040/P/2014, valid on February, 18, 2014 until February, 18, 2019. Indexed by DOAJ, Sinta, IPI 
infrastructure that can be used by the people is one of the indicators to figure out the level of poverty in one region. From the fulfillment of basic needs of both food and non food, Garut Regency is in the third position from the bottom of the list in West Java.

There are many programs that have been launched by the government to reduce poverty in West Java. The various poverty alleviation programs are implemented by the government through sectoral, regional, institutional, strategic and special policy approaches such as Inpres Desa Tertinggal (IDT) Presidential Instruction of underdeveloped Villages) and program Pengembangan Terpadu Antar Desa (PPTAD) (Integrated Development of villages Program) (Zulfida et al., 2015), (Kkesesra), Program Kesejahteraan Sosial kelompok Usaha Bersama keluarga (Prokesos KUBE) ( Social welfare effort of family business), Kredit Usaha kesejahteraan Rakyat (Kukesra) ( Credit for people's welfare business), Kredit Usaha Kecil menengah (Credit for small and medium-sized enterprises), Kredit Usaha Rakyat (KUR) (People's business credit), Jaring Pengaman Sosial (JPS) (Social security), P2KP, PNPM Mandiri, and others. However, these variable programs policies meet many obstacles and shortcomings at the implementation level. Therefore, the poverty rate remains high in West Java including Garut Regency.

During this time, the portrait of poverty is focused more on the economic aspects, whereas poverty is a multidimensional problem that is also related to social, political, institutional and cultural problems ( Suryawati, 2005). According to Chambers (1995) poverty is an integrated concept which has five dimensions, namely: (1) poverty; (2) helplessness ; (3) vulnerability to face emergency situations; (4) dependency; (5) alienation/ isolated both geographical and sociological. Chamber's five dimensions of poverty lead to social poverty.

The results of Aspiranti et al. (2016) identified Talegong District as one of the areas in the mountains of Garut regency which is economically categorized very poor and remote. Therefore, this study is aimed to identify whether Talegong is economically and socially poor regarding the fact that Talegong is one of the sub-districts. Remember Talegong sub-district is one of the districts in the mountains that is prone to natural disasters and is often isolated from contact with the outside areas in a rainy season.

\section{Research Method}

This research uses quantitative descriptive analysis with field survey method. Descriptive research quantitative method is used to describe the situation in the Talegong sub-district by using data collected in the field as well as publications from BPS or the rural government (Sugiyono, 2012). To see the picture of social poverty in Talegong sub-district, the researchers conducted field survey and in-depth interviews with village officials, rural secretaries, rural community development agencies (LPMDes), community leaders, and rural communities in seven villages of Talegong. The number of respondents was 35 people. Samples were conducted using purposive random sampling. While analytical techniques used descriptive statistics, which is quantitative research that aims to describe the state of social symptom as it is without viewing the relationships that exist (Bungin, 2011: 181).

The approach to poverty used BPS indicators elaborated with Chambers (1995) in which the social issues of poverty is related to poverty; physical, mental and social neglects; physical disabilities, mental and social; social disorder and behavioral aberrations; remoteness; victims of natural disasters; victims of physical, mental and social violence.

\section{Social Factors as the Source of Causes of Poverty}

According to Purwadinata (1997), poor means that a person does not have treasure, deprived, poor, very poor. In a broader definition, poverty can be defined as a condition of disability either individually, family, or group so that the condition is vulnerable to the emergence of other social problems.

Suyanto (2013: 4) has made a classification of poverty that is associated with the amount of rice consumption. In urban areas, a person is called poor when this person consumed less than 420 kilograms of rice per year and 320 kilograms per year for rural communities. A society is regarded as the poorest when they consume less than 180 kilograms of rice per year. 
The size of poverty is also introduced by UNDP as the size of poverty levels through the human poverty index (Human Poverty Index-HPI). Poverty is measured by the three main things that are absent: first, judging from the life expectancy of more than $30 \%$ of the population in less-developed countries where its life expectancy is not more than 40 years; Second, the basic education is measured by the percentage of adult illiterates; Third, the overall economic provisions (which is measured by the ease of access to health care and clean water plus the percentage of children under age five who are underweight) (Todaro, 2006).

The problem of poverty will never be solved simply because it uses an economic perspective. The process of development that has been going on for so long has to lead to the phenomenon of poverty with very strong characteristics, such as backwardness, remoteness, helplessness and loss. These characteristics are often considered as the worst derivation of the phenomenon of poverty. BPS defined the poverty criteria from social aspects (Zulkifli, 2013), namely: (1) poverty includes groups of people who have socio-economic disabilities or people that are vulnerable to poverty such as: poor families; socio-economic vulnerable families; people who live in a slum area; (2) Abandonment, including people who, for some reason, have physical, mental and social displacement, such as neglected toddlers, abandoned children and adolescents, including street children and child labors, abandoned adults, psychologically troubled families, and neglected elderly; (3) Disability, including people with physical and mental disabilities that are disturbed by their social function, such as: veteran disability, physical disability, mental disability (rationale, psychotic mental disorder), blind, deaf and speech impaired, patients with chronic diseases; (4) Social impairment and behavioral aberrations, including people who suffer fr om disruption of their social functions due to their inability to make normative social adjusment, such as prostitution, child conflicts with law/ delinquents, ex-convicts, narcotics victims, vagrants; beggars, HIV/AIDS victims and former chronic diseases; (5) Alienation and/ or being in a bad environment, including people who live in hard-to-reach, or scattered, or mobile areas, commonly called Remote Indigenous Communities; (6) Victims of Natural and Social Disasters, including people who are affected by the disasters, such as: natural disaster victims, and victims of social disasters that are caused by social conflicts and socio-cultural background; (7) Victims of violence, exploitation and discrimination, including people who suffered violence, such as child prostitution, trafficked and people who work in the worst situations, women as the victims of violence, elderly who are the victims of violence; and migrant workers as victims of violence, exploitation and discrimination.

In line with BPS, Chambers (1995) revealed a similar thing where social poverty can be viewed from the five dimensions: poverty, powerlessness, vulnerability to emergency situations, dependence and alienation both geographically and sociologically. To identify social poverty in Talegong, the researchers elaborated the indicators that have been developed by BPS and Chambers to see the poverty from the dimensions of poverty, neglect, disability, social security, alienation, natural disasters and nonviolent victims. Chambers suggestions in line with indicators that are developed by BPS.

\section{Characteristics of Talegong Sub District}

To understand the social factors that contribute to poverty in Talegong, the researchers conducted field studies and interviews with the rural officials, LPMDs, community leaders and rural people of Talegong. Before discussing the social factors that cause poverty, the researchers will explain the characteristic of Talegong as a very remote and the poorest regions in Garut. Talegong subdistrict has an area of about 19,896.94 hectares with boundary in the north of Pangalengan, Bandung Regency. In the east, it is bordered by Girimukti Village, Cisewu. In the south is Nyalindung Village, Cisewu. The western part is Cianjur Regency. In general, the counter of Talegong is a mountainous area. Hills with the lowest sea surface as high as 700 meters above the sea level and much of the land surface have a steep slope rail that causes Talegong to be prone to natural disasters.

Talegong oversees seven villages, namely Selaawi, Sukamaju, Sukamulya, Mekarmulya, Mekarmukti, Sukalaksana and Mekarwangi. Of the se ven villages, it turned out that Sukamulya Village is the 
area that has the largest population with a density of $6234,3.18 \mathrm{ha} /$ person. The village with the lowest population density is Village Mekarwangi (0.81) with the total population of 2,281 inhabitants.

Talegong is located not far from the border of Bandung City, precisely from Cukul Pangalengan. The distance from Bandung to the Talegong takes approximately 5 hours. Access road to the district is good but the subdistrict roads are poor. However, Talegong District is very far from the center of Garut city. The economic access of Talegong is easier to Garut regency than to Garut City, so it is not surprising that people sell their farming products with Pangalengan Subdistrict as their destination. The roads and streets in Telegong are already asphalt hotmix, but the conditions of the roads are poor and have a lot of holes. This is exacerbated by the contours of the road which is downhill and have sharp turns and caused the road conditions to be very unstable. To access one village with another village is difficult and time-consuming.

Talegong is geographically in the hills. Along the way are towering cliffs and steep cliffs on the other side. With the condition of these hills, it is not surprising that Talegong is prone to landslides, because when it rains, the loose soil cannot bear the rainwater and causes landslides. Landslide can occur in many points of varying length and depth when it rains. The landslide material often covers entire roads which can only be passed by one car.

Based on the status of the village, villages in Talegong sub-district are underdeveloped and left behind. The most underdeveloped villages are Selaawi Village, Sukamaju Village and Sukamulya Village. While the undeveloped villages are Mekarmulya, Mekarmukti, Sukalaksana and Mekarwangi.

There are some obstacles in physical relationships between the seven villages; the contours of mountainous areas, prone to landslide and lack of access to roads resulting in high poverty both economically and socially in seven villages in Talegong.

\section{Determinant Factors of Social Poverty in Talegong}

Referring to the poverty indicators developed by BPS and Chambers, there are seven indicators of social poverty used in this study: (1) poverty is the number of poor people who can not meet the needs properly; (2) displacement of physically, mentally and socially; (3) Disability includes physical and mental disability so as to disrupt social function. In Chambers version, this disability causes people to become dependent on the help of others and to be powerless to help themselves; (4) social disability and misbehavior includes people who have social problems because of their lack of abilities to make social adjustment; (5) Remoteness and isolation both geographically and sociologically so that people find it difficult to access economic resources appropriately; (6) victims of natural and social disasters; (7) Victims of violence, exploitation and discrimination. The following is a comprehensive analysis of social poverty in Talegong.

\section{Image of Poverty in Talegong}

Poverty includes groups of people with social disabilities, economic or people who tend to be poor, like families of the poor, socio-economic vulnerable families, and people who live in slums. In this case, the vulnerable society becomes poor because there are things that are beyond their control. For example, a family becomes poor because the head of the family suddenly fell ill or family business went bankrupt.

Based on Talegon's data BPS (2017), in 2016 the number of poor people in Talegong was as many as 2727 people spread in 7 villages. Sukamaju, Sukamulya and Sukalaksana are the three regions that have the highest number of poor people. In Sukamulya and Sukalaksana villages there are many remote areas that are difficult to reach, so that people have difficulty in accessing adequate resources. To meet the basic needs, people generally use the existing natural resources in their area.

For example, opening new field to grow vegetables in the hills so that the soil becomes more loose and very vulnerable to landslides. Another impact is the reduced supply of clean water due to the destruction of the water absorption area, so that people have difficulty in getting clean water to meet their daily needs and farm irrigation especially during the dry season.

Other than Selaawi, the other villages that have bad access to water sources are 
Table 1

Clean Water Source in Talegong in 2016

\begin{tabular}{|c|c|c|c|c|}
\hline Villages & Type/Source & Units & $\begin{array}{c}\text { Utilization } \\
\text { (per family) }\end{array}$ & Condition \\
\hline Selaawi & $\begin{array}{l}\text { a. Spring } \\
\text { b. Dug well } \\
\text { c.River }\end{array}$ & $\begin{array}{c}47 \\
655 \\
1\end{array}$ & $\begin{array}{c}650 \\
655 \\
\text { Public }\end{array}$ & $\begin{array}{l}\text { Damaged } \\
\text { Good } \\
\text { Fair }\end{array}$ \\
\hline Sukamaju & $\begin{array}{l}\text { a.Dug Well } \\
\text { b. Clean water tank } \\
\text { c. Retention Basin } \\
\text { d. Spring }\end{array}$ & $\begin{array}{l}36 \\
11 \\
23 \\
43\end{array}$ & $\begin{array}{l}36 \\
\text { Public } \\
\text { Public } \\
725\end{array}$ & $\begin{array}{l}\text { Good } \\
\text { Fair } \\
\text { Fair } \\
\text { Good }\end{array}$ \\
\hline Sukamulya & $\begin{array}{l}\text { a. Spring } \\
\text { b. Dug well } \\
\text { c. River }\end{array}$ & $\begin{array}{c}48 \\
178 \\
5\end{array}$ & $\begin{array}{l}120 \\
178 \\
240\end{array}$ & $\begin{array}{l}\text { Good } \\
\text { Fair } \\
\text { Fair }\end{array}$ \\
\hline Mekarmulya & $\begin{array}{l}\text { a. Spring } \\
\text { b. Dug well } \\
\text { c. River }\end{array}$ & $\begin{array}{c}40 \\
25 \\
9\end{array}$ & $\begin{array}{c}165 \\
43 \\
995\end{array}$ & $\begin{array}{c}\text { Fair } \\
\text { Good } \\
\text { Damaged }\end{array}$ \\
\hline Mekarmukti & $\begin{array}{l}\text { a. Spring } \\
\text { b. Dug well } \\
\text { c. Household well } \\
\text { d. River }\end{array}$ & $\begin{array}{l}285 \\
160 \\
321\end{array}$ & $\begin{array}{c}1,711 \\
875 \\
753\end{array}$ & $\begin{array}{l}\text { Good } \\
\text { Fair } \\
\text { Good }\end{array}$ \\
\hline & & 17 & 1,321 & Fair \\
\hline Sukalaksana & $\begin{array}{l}\text { a. Tap Water } \\
\text { b. Dug well } \\
\text { c. Public water } \\
\text { d. River }\end{array}$ & $\begin{array}{l}- \\
5 \\
- \\
-\end{array}$ & $\begin{array}{c}99 \\
5 \\
170 \\
100\end{array}$ & $\begin{array}{l}\text { Good } \\
\text { Poor } \\
\text { Poor } \\
\text { Poor }\end{array}$ \\
\hline Mekarwangi & $\begin{array}{l}\text { a. Spring } \\
\text { b. Dug well } \\
\text { c. Well (pump) } \\
\text { d. Public water }\end{array}$ & $\begin{array}{c}- \\
45 \\
3 \\
-\end{array}$ & $\begin{array}{c}36 \\
45 \\
3 \\
698\end{array}$ & $\begin{array}{l}\text { Good } \\
\text { Good } \\
\text { Good } \\
\text { Fair }\end{array}$ \\
\hline
\end{tabular}

Source: Data on the villages of Talegong 2017

Table 2

Number of the Poor, Farm Workers and Inadequate Houses in Talegong in 2016

\begin{tabular}{lccc}
\hline \multicolumn{1}{c}{ Villages } & $\begin{array}{c}\text { Number of The Poor } \\
\text { Family Units }\end{array}$ & $\begin{array}{c}\text { Number of } \\
\text { Farmworkers }\end{array}$ & $\begin{array}{c}\text { Number of inappropriate } \\
\text { houses } \\
\text { (per family unit) }\end{array}$ \\
\hline Selaawi & 441 & 981 & 52 \\
Sukamaju & 566 & 917 & 225 \\
Sukamulya & 541 & 1.046 & 196 \\
Mekarmulya & 288 & 826 & 100 \\
Mekarmukti & 208 & 2.153 & 20 \\
Sukalaksana & 598 & 850 & 804 \\
Mekarwangi & 145 & 212 & 60 \\
Total & $\mathbf{2 , 7 2 7}$ & 6,985 & 1,457 \\
\hline
\end{tabular}

Sukalaksana and Mekarmulya. The condition of water system and irrigation in the village of Sukalaksana are very unreliable. Irrigation channels are poorly maintained, whereas irrigation channels are very important for managing agricultural land. In effect, the rice/ paddy fields do not function optimally because there is no water to plant rice/ paddy.

A large number of poor people in Talegong is caused due to the low level of incomes. Based on the results of interviews with the community of Talegong, the income per capita of people in Talegong is only ranged from 500,000 - 600,000 Rupiahs per month (under the World Bank's minimum requirement of $\$ 2$ per day). This means that the income earned by the community is not able to meet basic needs such as adequate caloric needs to run their daily activities. The condition of the area is very prone to landslides and causes their farm products to not be sold in the market so that they cannot make an income from the agricultural products to cover 
the needs of family's everyday needs. The following is the development of the number of poor people, the number of farm workers and inadequate houses in Talegong.

Most people of Talegong are farm workers and small farmers (who have less than one-hectare farming area) whose income is not fixed and inadequate. As a farm worker, the average income per day is 20,000 rupiahs with lunch or in total of. 30,000 rupiahs. At planting time, these workers have an income but after that they are jobless until harvest time. Farmers in Talegong are still traditional. This means that they cannot utilize the agricultural lands to its best. For example, farmers only plant a single plant species. People are very rare to have variety of plants cultivation (tumpang sari) or mina padi. The low level of education and the absence of agricultural extension workers have caused the farmers have limited knowledge. Agricultural management is based solely on the experience of daily activities. This is in line with the findings by Jajang et al. (2013), the average quality of education in the agricultural sector is low in Central Java, resulting in low labor productivity and the impact of persistently high rates of rural poverty.

In 2016, the number of people who did not have appropriate houses in Talegong as many as 1,457 units in Sukalaksana, Sukamaju and Sukamulaya. These three villages had the highest numbers of people who did not have appropriate houses. This happened because it was difficult to have construction materials and they have low income and this situation made people in these three areas to be willing to occupy an inappropriate house, while people in Mekarwangi, Mekarmukti and Selaawi had a greater number of better houses to occupy.

One of the causes of the high rate of poverty in the villages of Talegong is the low rate of school participation (APS) (Angka Partisipasi Sekolah). Talegong has many school infrastructures for a nine years school obligation program. Primary to junior high schools are spread evenly in each village in Talegong. Meanwhile, senior high schools are only in Sukamulya, Sukalaksana and Mekarwangi Villages. This condition becomes an obstacle factor for the community to continue their study to a higher level. Although the school participation (APS) is low, there are some residents who have earned their master degree and postgraduate degree. However, these qualified human resources do not return to their hometown. These community groups prefer to pursue a career in a bigger city, so that the human resources that build the village are lower educated human resources. In effect, innovations to accelerate village development do not occur.

Regarding the welfare stage, $44.16 \%$ of people of Talegong are still at the preprosperous level. This means there are still many people who have not been able to meet their basic needs. In Talegong, Sukamaju village has the highest number of poor families ( 830 families or $19.30 \%$ ). The village in the first and the second level of prosperousness is Sukamulya (703 family units and 404 family units respectively).

\section{Physical, Mental, and Social Neglect as Social Poverty Determinants in Talegong.}

Neglect is a condition of neglecting or abandoning children and elderly for various reasons that can not meet their basic needs physically, mentally and spiritually (Amaludin, 2012). Physical, mental and social abandonment often cause social poverty. Community groups who are physically, mentally and socially abandoned find it difficult to grow and develop normally. The effect is these individuals are psychologically abnormal and have more difficulty in accessing the resources than people who live normally. According to village officials and people in seven villages, there are no people who are abandoned by their families, both physically, mentally and socially.

\section{Physical, Mental and Social Disabili- ties as the Cause of Social Poverty in Talegong}

A disable is someone who has the ability to perform activities differently compared with the average person (Purwadinata, 1997). These disabilities include disruptions, activity limitations and participation restrictions. Meanwhile, a person with disability is a person with a disturbing physical or mental disorder, which may interfere with or constitute a barrier and obstacle for him/her to exercise in a manner consisting physically, mentally, physically and mentally 
MIMBAR, Vol.34 No $1^{\text {st }}$ (June) 2018 pp. 33-42

Table 3

Numbers of Disabilities in Talegong in 2016

\begin{tabular}{|c|c|c|c|c|c|c|c|c|c|}
\hline \multirow[b]{2}{*}{ Village } & \multicolumn{7}{|c|}{ Physical Disabilities } & \multicolumn{2}{|c|}{$\begin{array}{c}\text { Mental } \\
\text { Disabilities }\end{array}$} \\
\hline & Blind & $\begin{array}{c}\text { Speech } \\
\text { Impairment }\end{array}$ & Deaf & illiterate & $\begin{array}{c}\text { Physical } \\
\text { Impair- } \\
\text { ment }\end{array}$ & Paralyzed & Harelip & $\begin{array}{c}\text { Mental } \\
\text { retarda- } \\
\text { tion }\end{array}$ & $\begin{array}{l}\text { Depres- } \\
\text { sion }\end{array}$ \\
\hline Selaawi & 4 & 1 & 7 & 0 & 0 & 0 & 0 & 2 & 1 \\
\hline Sukamaju & 13 & 10 & 5 & 0 & 6 & 0 & 1 & 0 & 0 \\
\hline Sukamulya & 4 & 6 & 3 & 0 & 10 & 3 & 1 & 3 & 3 \\
\hline Mekarmulya & 1 & 3 & 43 & 81 & 2 & 2 & 2 & 4 & 0 \\
\hline Mekarmukti & 3 & 6 & 11 & 0 & 1 & 0 & 3 & 3 & 3 \\
\hline Sukalaksana & 17 & 2 & 0 & 0 & 12 & 0 & 0 & 2 & 1 \\
\hline Mekarwangi & 3 & 3 & 3 & 0 & 0 & 1 & 1 & 0 & 5 \\
\hline Total & 45 & 31 & 72 & 81 & 31 & 6 & 8 & 14 & 13 \\
\hline
\end{tabular}

Source: Data on the villages of Talegong, 2017

handicapped. Physical, mental and social disabilities are some of the factors that cause social poverty. A person with physical, mental and social disabilities will have difficulties in doing normal-person activities to survive; these people rely on family or neighborhood assistance. This group has difficulty to interact with the surrounding environment so that the condition is alienated with the surrounding environment. The rate of physical and mental disabilities of Talegong is high. The most common physical defects suffered by the inhabitants are deafness, followed by blindness, muteness and being physically impaired. Most of mental disabilities suffered by the public are mental retardation and depression.

The isolation of an area positively correlates with the number of people with physical and mental disabilities in the villages of Talegong. This is shown in the above data by the number of people with physical and mental disabilities in Sukamulya, Sukamaju and Sukalaksana Villages. These three villages are more isolated compared to other villages. The high rate of disability in these villages is due to the low level of community education so that the public does not have much information in the fulfillment of good nutrition and adequate intake of vitamins and minerals during pregnancy and the difficult access to health services. The availability of health services is one of several ways to break the level of poverty in the village because if the community is healthy then the community will work more productively which then will affect the increase of income and public expenditure. The outcome is that the level of poverty in the village can be lowered.

\section{Social Disability and Deviant Behavior as the Cause of Social Poverty in Talegong}

Deviant behavior is defined as a deviant behavior, actions or one's response to the environment as opposed to the norms and laws that exist in the community (Purwadinata, 1997). In society, all human actions are limited by the rules (norms) to act and behave in accordance with the rules prevailing in society. The types of deviant behavior that often occur in a community are such as a drug abuse, drugs and alcohol, unmarried relationships and criminal actions (theft, mugging, murder) and others. People that engage in deviant behavior from norms and ethical norms in society will usually be excommunicated by the community itself. The effect of the activities of people who perpetrate irregularities is very limited and live in poverty due to the difficult access to resources.

The interviews with village officials provided some information that in the villages in Talegong there are no narcotic addicts, beverages, commercial sex workers and HIV patients. Community leaders have revealed that a very religious life in Talegong keeps people from doing things that deviate from the religious provisions. Thus, although living 
Table 4

Remote Area/Community in Talegong, in 2016

\begin{tabular}{lc}
\hline \multicolumn{1}{c}{ Village } & Remote Areas \\
\hline \hline Selaawi & - \\
Sukamaju & - \\
Sukamulya & Kp. Datarkupa 01/06 \\
& Kp. Ciranca 04/07 \\
& Kp. Cilipung Kompak 05/03 \\
& Kp. Pasir Tando 05/07 \\
& Kp. Pasir Hayam 04/06 \\
& Kp. Pasir Hirung 02/05 \\
Mekarmulya & - \\
Mekarmukti & - \\
Sukalaksana & Dusun Cihanjuang \\
Mekarwangi & - \\
\hline
\end{tabular}

Source: Documents of Talegong, 2017

in poverty, the people of Talegong do not engaged in activities that are prohibited by religion or the state.

\section{Alienation and Remoteness as the Cause of Social Poverty in Talegong}

Alienation comes from the word "alienate" which means excluded from intercourse, separated from others or remote. The cause of someone being alienated is because of his behavior which is unacceptable or justified by society or because of the inherent shortcomings in themselves so that they withdraw from the environment (Purwadinata, 1997). Alienation can also occur because a group of people are in an area that is difficult to reach due to the absence of adequate road infrastructure, so that people are isolated from the outside world. Remoteness and isolation and/or being in a bad neighborhood include people who live in an isolated or scattered or mobile areas that are often called Remote Indigenous Communities. Alienation in Talegong mostly refers to the concept of community isolation because there are some villages that are difficult to reach due to the inadequate road infrastructure condition. Pathways with muddy conditions make it difficult for the people to adequately meet their basic needs. Alienation in Talegong is not due to bad behavior of the community that can not be accepted by the environment, but because the condition of the region is prone to natural disasters. There are many landslide points with the depth and length of the landslide causing people to accept the situation. The distance between Sukalaksana village and Sukamaju village can be covered in approximately 45 minutes. The trip to these villages requires travel through many broken streets, holes in the streets, and several landslides. These villages can be reached through a good provincial road but as soon as people arrive in the villages' gate the roads are perforated and damaged. Most roads in Talegong are damaged with the contours of the road that are still rocky and compacted. The difficult access to this path is one of the still many remote areas in Talegong. There are many remote areas in Sukamulya village because of the inappropriate road access conditions. In addition, these villages are located too far from other villages.

Another isolated area is located in Cihanjuang, Sukalaksana which is similar to other isolated areas: this village has roads that are difficult to be accessed because of the remote location plus muddy road conditions.

Remote villages generally have a greater number of poor people than areas with adequate road access. The remoteness and isolation have caused social poverty in Sukalaksana and Sukamulya villages.

\section{Victims of Natural Disaster and So- cial Disaster as the Causes of Social Poverty in Talegong}

The act no. 24 of 2007 about disaster management writes the definition of disaster as a series of events that threaten and disrupt the lives and livelihood caused by natural factors and or human factors that cause 
loss of life, environmental damage, loss of property and psychological impact. Natural disasters are caused by natural events such as earthquakes, tsunamis, volcanoes, floods, droughts, hurricanes and landslides. The effects of natural disasters not only damage property but also people's lives. Destruction of property causes a person to become vulnerable to social and economically poverty.

Talegong is a mountainous and hills contour that is prone to landslide when the frequency of rain is relatively high. Based on the data of BPPD of Garut Sub-district, in February 2018, there were severe landslides in Talegong. The landslide occurred in Kampung Ciwaru in Sukamulya village. The landslide happened after a day of heavy rain. The landslide cut the access to other villages. The landslide covered the roads of 30 meters wide and 4 meters tall respectively. Furthermore, the data of BPPD Garut recorded throughout the year 2015 that Garut has faced many disasters; 16 fires, 56 landslides, and nine ground crack points that were spreaded in several sub-districts in Garut. Based on the interview with the leader (Camat) of Talegong Sub-district, in 2016 there was the cracks and plunge of land (250 meters with $25 \mathrm{~cm}$ crack height) (Prakarsa, et al., 2016). Meanwhile, in November 2013, the natural disaster that occurred in Garut Regency caused 20 people to be injured and 3,185 houses damaged. From January to November 2013 there were 296 natural disasters. In 2013, out of the number of landslides in Garut Regency, 11 points was in Talegong-Cisewu which resulted in the dissolution of transportation routes (Zulmunir, 2013). The disconnected roads isolated the areas of seven villages in Talegong. The effect was that the community could not fulfill their basic needs in a sustainable way because the area was isolated.

\section{Victims of Violence, Exploitation, and Discrimination as a Cause of Extreme Poverty}

Victims of violence (Korban tindak kekerasan-KTK) ) are both individuals, families or groups affected by violence in the form of abandonment, abusement, exploitation, discrimination and other forms of violence and those who are in situations that endanger themselves, and affecting social function (Kemensos, 2017). Based on interviews with village officials and villagers of Talegong, there was no information related to individuals who were subjected to violence, exploitation or discrimination. Social poverty caused by inappropriate action or behavior were not found in the villages of Talegong.

\section{Conclusion}

Of the seven factor determinants of poverty socially in District Talegong, there are four indicators as determinant factors of social poverty in Talegong: first, poverty, remote villages have a higher poverty rate than villages that are easily accessible by outsiders. Second, in Talegong many people are physically and mentally disabled especially in isolated areas. Third, Alienation and remoteness have become one of the main causes of social poverty in Talegong. Bad road infrastructures in several villages have contributed to the low quality of life. People find it difficult to access resources needed for a decent life. People in the remote areas make the environment as the only source of life so that forest destruction occurs and at some point has an effect on the provision of clean water to meet daily needs and farming needs. Fourth, being prone to natural disasters. Many avalanche points in the rainy season isolate the villages from the means of transportation in some villages and hamlets in Talegong. The isolation caused by natural disasters has contributed to the increasing societal poverty in Talegong. While the other three factors are physical, mental and social neglect factors. Despite being geographically isolated, social disability and behavior deviation against the norms of religion and society and the factors of the victims of physical, mental and social abuse are not found in the villages of Talegong although it is geographically very isolated.

\section{References}

Amaludin, Zahrul. (2012). "Ketelantaran sebagai Penyebab Kemiskinan." http:// social-welfare.blogspot.co.id/2012/09/ keterlantaran.html.

Aspiranti, Tasya, Ima Amaliah, Sri Suwarsi, Pupung Purnamasari. (2016)."Pemetaan Wilayah Kemiskinan di Jawa Barat Berdasarkan Indikator Ekonomi."Laporan Penelitian. Bandung: LPPM Universitas Islam Bandung

Badan Pusat Statistik. (2017)."Jawa Barat dalam Angka." Jawa Barat: BPS.

Badan Pusat Statistik. (2017). "Kecamatan Talegong dalam Angka."Jawa Barat: BPS 
Bungin, Burhan. (2011)."Metodologi Penelitian Kuantitatif: Komunikasi, Ekonomi dan Kebijakan Publik serta Ilmu-ilmu Sosial Lainnya." Edisi Kedua, Jakarta: Kencana Perdana Media Group

Chambers, Robert. (1995). "Poverty and Livelihood: Whose Reality Counts." Discussion Paper 347, Brighton: Institute of Development Studies.

Hermawan, Iwan. (2012)."Analisis Eksistensi Sektor Pertanian terhadap Pengurangan Kemiskinan di Perdesaan dan Perkotaan."Mimbar: Jurnal Sosial dan Pembangunan. Vol. 28. No. 2 (Desember). 135-144. Bandung: LPPM Unisba.

Jajang, Asep Saefuddin, I. Wayan Mangku,Siregar, Hermanto Siregar. (2013)."Analisis Kemiskinan Menggunakan Model Panel Spesial Statik."Mimbar: Jurnal Sosial dan Pembangunan, Vo. 29 No. 2 (Desember). 195-203. Bandung: LPPM Unisba.

Kemensos, (2017)."Korban Tindak Kekerasan sebagai Penyebab Kemiskinan." https:// www. kemsos.go.id/content/korbantindak-kekerasan-ktk.

Purwadinata, W.J.S.(1997). "Kamus Umum Bahasa Indonesia." Jakarta: Balai Pustaka.

Prakarsa, Aditya, Arie Nugraha, Dinny Mutiah, Rochmanuddin. (2016). "Kaleideskop 2016; Peta Banjir Bandang di Bumi Garut."
Liputan6.com, 20 Desember

Sugiyono. (2012). "Metode Penelitian Kuantitatif Kualitatif dan R\&D." Bandung: Alfabeta

Suyanto, Bagong. (2013). "Anatomi Kemiskinan Dan Strategi Penanganannya." Malang Penerbit Intrans Publishing

Suryawati, Chriswardani. (2005)." Memahami Kemiskinan Secara Multidimensional." Jurnal MPK. Vol. 08, No.03 (September)

Todaro M.P. (2006). "Pembangunan Ekonomi di Dunia Ketiga." Jakarta: Penerbit Erlangga

Zulfida, Ida, Akhmad Fauzi, Ernan Rustiadi, Yusman Syaukat. (2015)." Kinerja Program Nasional Pemberdayaan Masyarakat Mandiri Perdesaan di Kabupaten Bandung." MIMBAR: Jurnal Sosial dan Pembangunan, Vol. 31, No. 2 (Desember): 307-318, Bandung: LPPM Unisba.

Zulkifli, Arif. (2013)."Kemiskinan di Indonesia atau Poverty in Indonesia."Diunggah dari https://bangazul.com/potret-kemiskinandi-indonesia/ pada tanggal 22 Agustus 2017.

Zulmunir, Sigit. (2013)." Garut Daerah Paling Rawan Bencana di Indonesia." https://nasional.tempo.co/read/538487/ garut-daerah-paling-rawan-bencana-diindonesia. 